\title{
Stabilization and solidification of tailings from a traditional gold mine using Portland cement
}

\author{
Ranno Marlany Rachman ${ }^{\dagger}$, Ayi Syaeful Bahri, Yulinah Trihadiningrum \\ Department of Environmental Engineering, Institut Teknologi Sepuluh Nopember, Surabaya 60111, Indonesia
}

\begin{abstract}
The traditional gold mining in Kulon Progo district, Special Region of Yogyakarta Province produced tailings containing mercury (Hg) from the gold amalgamation process. Mercury accumulated in tailings has $164.19 \mathrm{mg} / \mathrm{kg}-383.21 \mathrm{mg} / \mathrm{kg}$ in total concentration. Stabilization/solidification $(\mathrm{S} / \mathrm{S})$ is one of the remediation technologies to reduce waste pollution. Portland cement is one of the additive materials in S/S that effective encapsulates heavy metal waste. The aim of this research is to know the optimum composition of tailings mixture with Portland cement in $\mathrm{S} / \mathrm{S}$ process. This research used variation of tailings composition. Variation of Portland cement composition with tailing are 100:0, 90:10, 80:20, 70:30, 60:40, 50:50, 40:60, 30:70, 20:80 and 10:90. The result of this study found that the optimum composition of Portland cement: tailings was 10:90, with compression test of $257 \mathrm{ton} / \mathrm{m}^{2}$ and TCLP test was $0.0069 \mathrm{mg} / \mathrm{L}$. The compression test results were in accordance to US EPA Standard quality of $35 \mathrm{ton} / \mathrm{m}^{2}$. TCLP test results meet the standard of Indonesian Government Regulation No. 101 Year 2014 of $0.05 \mathrm{mg} / \mathrm{L}$.
\end{abstract}

Keywords: Mercury, Portland cement, Stabilization/solidification, Tailings

\section{Introduction}

Tailing is a waste generated from mineral processing [1]. The mineral processing is carried out by amalgamation techniques that mix mineral ore with mercury to form amalgam with water as a medium [2]. Traditional gold mining in Kulon Progo uses a simple technique using mercury in the amalgamation process. According to Larasati et al. [3], tailings from gold processing overflowed from existing shelters and flowed out to the surrounding environment. In some mine sites, tailings form a heap without further processing. According to Ogola et al. [4], there are several heavy metals contained in the tailings from the amalgamation process, such as mercury, lead, arsenic, and cadmium. Besides a mercury concentration test, this study also measured heavy metal concentrations such as As, $\mathrm{Pb}, \mathrm{Cd}, \mathrm{Cr}$ and $\mathrm{Ni}$ but the result was still below the specified environmental standard, so it can be neglected. Mercury is the most dominant heavy metal in tailings from the traditional gold mining process [5]. According to Government Regulation no. 101 Year 2014 on the Management of Hazardous and Toxic Wastes [6], tailings from mineral processes fall into category 2. The resulting tailings shall be kept in accordance with the Decision of the Head of the Environmental Impact Management Agency No. 1 of 1995 on Technical Procedures and Technical Requirements for the Storage and Collection of Hazardous and Dangerous Wastes. Based on the results of the tailings sampling test in mining, the total mercury concentrations ranged from $164 \mathrm{mg} / \mathrm{kg}-314$ $\mathrm{mg} / \mathrm{kg}$ which compare to applied regulation standard, the maximum total concentration of mercury permitted in the tailings is $75 \mathrm{mg} / \mathrm{kg}$. Mercury concentration in the tailings has exceeded the specified quality standard, means that tailing processing techniques is required to reduce the pollution level to predetermined quality standards.

Remediation technology using physical/chemical processes consists of in situ and ex situ [7]. The in situ remediation are chemical oxidation, electrokinetic separation, fracturing, soil flushing, soil vapor extraction, solidification/stabilization (S/S). Whereas ex situ remediation are chemical reduction/oxidation, dehalogenation, separation, soil washing, S/S [8].

The remediation technologies that can be applied either in situ or ex situ using physical chemical process are S/S and chemical oxidation. In this research is using $S / S$ because it can reduce mercury waste in the tailings. Andrés et al. [9], claimed that S/S technology works by limiting the contamination of hazardous material compounds.
This is an Open Access article distributed under the terms of the Creative Commons Attribution Non-Commercial License (http://creativecommons.org/licenses/by-nc/3.0/) which permits unrestricted non-commercial use, distribution, and reproduction in any medium, provided the original work is properly cited.

Copyright (C) 2018 Korean Society of Environmental Engineers
Received August 10, 2017 Accepted January 26, 2018

${ }^{\dagger}$ Corresponding author

Email: ranno_2004@yahoo.com

Tel: +62-8114007575 Fax: +62-315928387

ORCID: 0000-0001-7789-790X 
The advantage of S/S technology for hazardous waste treatment are cheap, environmentally friendly, and easy to apply [10]. In $\mathrm{S} / \mathrm{S}$ technology, the waste is converted into solid compounds which directing on reducing the rate of contaminants [11]. The S/S technique requires an additional binder to encapsulate the physical and chemical contaminants to become more stable formation than before [12]. Some additive materials that can be used in $S / S$ process are Portland cement, fly ash, lime, clay, zeolite [13].

The most common binder used in S/S technology is Portland cement due to its ease to obtain and it can be applied to various types of waste [14]. The S/S technique combine with Portland cement is very effective to bind inorganic compounds [15]. In the other hand, disadvantages of $\mathrm{S} / \mathrm{S}$ process can not be used for waste containing hydrocarbons [16].

The cost effectiveness of remediation techniques can be determined by type of waste. Moisture content in the sludge drives up costs compared to solid; contaminant concentration and type determine the amount of reagents added to the waste to attain the required treatment standards. Size of the mobile S/S system (choosing the correct size mobile $\mathrm{S} / \mathrm{S}$ system to adequately handle the throughput of waste volume). Cost analysis (the estimated costs by common unit of measure to apply S/S technology at sites of varying size and complexity [17].

This study will tested the ability of S/S technology to stabilize mercury contained in the tailings by using a mixture of Portland cement. The characteristics of tailings should be known as considerations in performing $\mathrm{S} / \mathrm{S}$. In the $\mathrm{S} / \mathrm{S}$ techniques, variations of Portland cement composition and tailings will affect product quality. The optimum composition of Portland cement and tailings should be considered for obtaining the desired S/S product, with the lowest amount of additional portland cement.

\section{Materials and Methods}

\subsection{Materials}

Ordinary Portland Cement (OPC) supplied from PT Semen Indonesia was used throughout this research. Tailings were taken at the Kulon Progo gold mine site at 5 specific locations. Sampling was done by using a core sampler which refers to US EPA [18]. The main sampler method used in this research is sub sampling and composite sampling (multiple core samples) with variation of depth are $30 \mathrm{~cm}, 60 \mathrm{~cm}$ and $90 \mathrm{~cm}$ for each location. Each sample was inserted into Poly Ethylene Terephthalate (PET) plastic and labeled, then inserted into an ice box with temperature of $4^{\circ} \mathrm{C}$ and brought to the laboratory for analysis of total mercury concentrations and tailing characteristics. The results of the five samples sites are composited into one sample based on the depth. The tailings sample location can be seen in Fig. 1 [19].

\subsection{Test of Mercury and Tailings Characteristics}

All samples were analyzed soil physical characterization based on particle size distribution analysis refers to ASTM D422. Whereas the test for chemical characteristics i.e. water content test is done by gravimetric method and $\mathrm{pH}$ is measured by $\mathrm{pH}$-meter. Particle size analysis methods and chemical characteristics of soil samples were performed at the Soil Mechanics Laboratory and Stone in Civil Engineering FTSP ITS. Mercury level test was conducted at LPPT UGM Yogyakarta by using Mercury Analyzer Type VM-3000. All samples were analyzed twice.

\subsection{Manufacturing of Test Material}

The test object is made by using a mold specimen's cuboid with $5 \mathrm{~cm}$ size per side. Variations in the composition of the specimen between Portland cement and tailings are 100:0; 90:10; 80:20; 30:70; 60:40; 50:50; 40:60; 30:70; 20:80 and 10:90. The procedure of stirring, preparing the specimen, compacting and treating the specimens shall refer to SNI 2493: 2011. The determination of the water requirement for the manufacture of the specimen is performed by a normal consistency test using Vicat tool. Cement, tailings and water are mixed until homogen and printed using a specimen mold.

\subsection{Mortar Treatment (Curing)}

The mortar treatment done by kept the mortar moist to prevent crack in the test objects. Mortar was placed in the room temperature for $28 \mathrm{~d}$. In this study, moisture curing was performed by placing the test objects around a bucket of water and sealed using a large tub. The treatment aimed to minimize the leaching of heavy metals contained in Portland cement: tailing mortar.

\subsection{Compressive Strength Test}

A compressive strength test was performed by using ASTM C109-93 test method. Compressive strength test was performed on a mortar that had been through the curing process for $28 \mathrm{~d}$. Compressive strengths of specimens were measure using Toorse Universal Testing Machine. Compressive strength test is performed to determine the maximum load that can be received by the specimen. The quality standard of compressive strength is $10 \mathrm{ton} / \mathrm{m}^{2}$ based on the Decree of Head of the Indonesia Environmental Impact Management Agency (Kepka Bapedal) No. 3 of 1995 [20].

\subsection{TCLP Test}

This is a decomposition method using an extraction method containing glacial acetic acid with a low $\mathrm{pH}$. The rotation-agitation process in this test was performed with a rotary agitator at $30 \pm 2 \mathrm{rpm}$ speed for $18 \pm 2 \mathrm{~h}$. The sample solution was precipitated and the filtrate is taken. The filtrate is stored in a brown glass bottle and tested for mercury concentration. Mercury level tests were held at the Laboratory.

The quality standard of TCLP test is max $0.05 \mathrm{mg} / \mathrm{L}$ according to Government Regulations of Indonesia No. 101 of 2014 [6]. The TCLP test used US EPA Method 1311 [21].

\subsection{Data Analysis and Conclusions}

The analysis includes the discussion of the relationship between water requirements, compressive strength values and TCLP test results on the composition between Portland cement and tailings. The optimum composition is determined by looking at the quality standards of each test with comparison of lowest portland cement usage. 


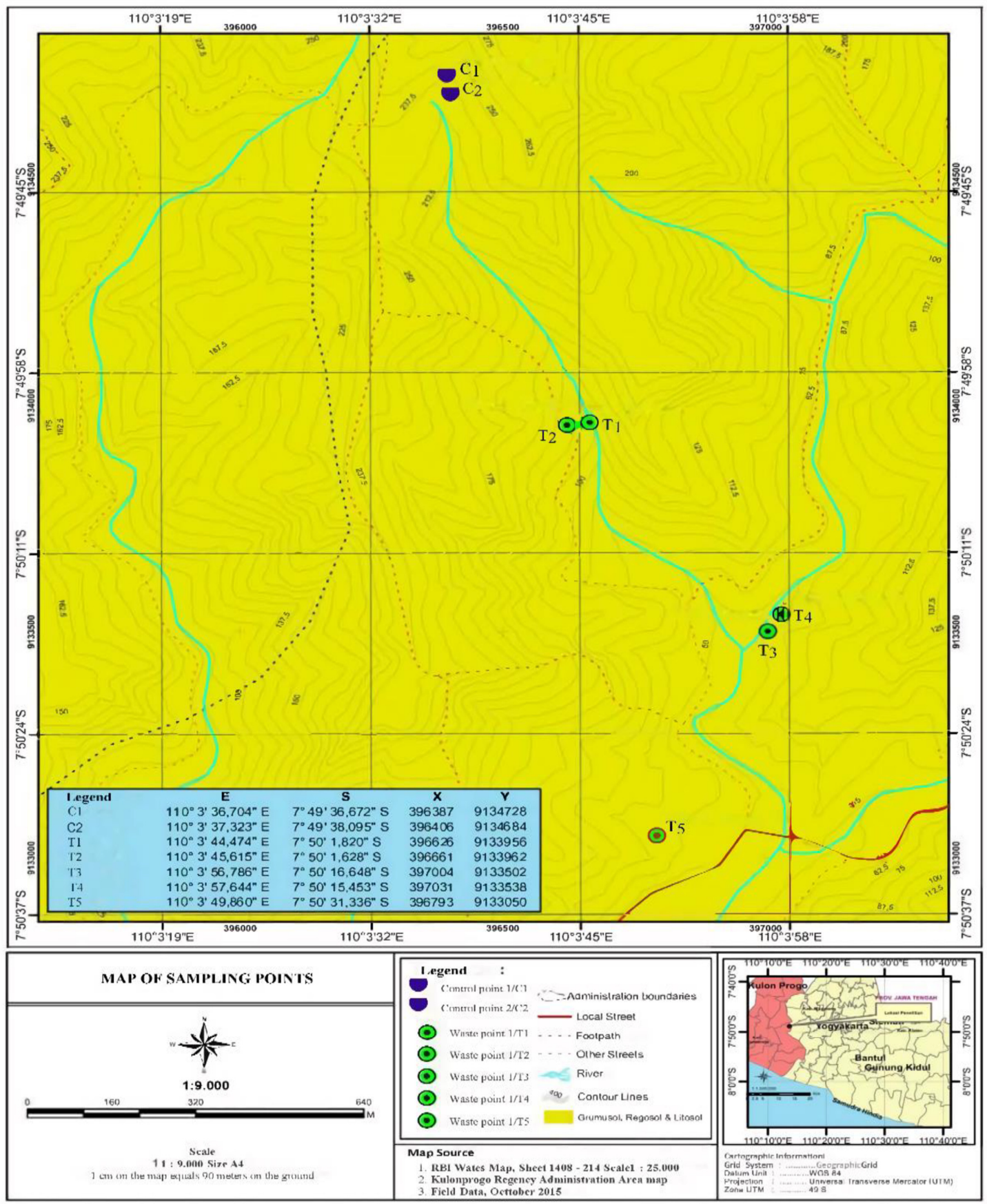

Fig. 1. Map of soil sampling location (Rachman et al. 2017).

\section{Results and Discussion}

\subsection{Characteristics of Soil Samples}

Materials used in this study are Portland cement type I and tailings. Sampling activities conducted on October 2015. The soil samples of the mine site were physically dominated by sand, silt and clay. Physical characterization of tailings can be seen in Table 1.
Based on soil texture triangle of the total content of each type of grain, tailings including sandy loam category (Fig. 2). The test result of chemical characterization of soil samples such as $\mathrm{pH}$ and total mercury concentration (Table 2). Compressive strength test was performed on each variation of the composition between Portland cement and the tailings formed into mold (duplicate) on each specimen. The value of compressive strength can be seen in Table 3 . 
In Table 3, it can be seen that all specimens met the minimum required of compressive strengths with the compressive strength value of $53 \mathrm{ton} / \mathrm{m}^{2}$ to $3,895 \mathrm{ton} / \mathrm{m}^{2}$. The highest compressive strength value was on the 80:20 composition, and the lowest is in the 10:90 composition.

The existence of Portland cement would add compressive strength value to the specimen. According to Pollard et al. [22], the hydration reaction of cement will produce calcium silicate

Table 1. Physical Characterization of Tailings

\begin{tabular}{lcccc}
\hline \multicolumn{1}{c}{ Soil fraction } & $\begin{array}{c}\text { Particle size } \\
(\mathbf{m m})\end{array}$ & $\begin{array}{c}\text { Content } \\
\text { (\%) }\end{array}$ & $\mathbf{p H}$ & $\begin{array}{c}\text { water content } \\
\text { (\%) }\end{array}$ \\
\hline Gravel & $\geq 4.76$ & 1.86 & & \\
Sand & & & & \\
$\quad$ - Rough & $\geq 2.00$ & & & \\
$\quad$ - Medium & $\geq 0.425$ & 55.17 & 6.78 & 13.24 \\
$\quad$ - Fine & $\geq 0.075$ & & & \\
Silt & $\geq 0.0055$ & 30.69 & & \\
Clay & $\geq 0.0001$ & 12.27 & & \\
\hline
\end{tabular}

Table 2. Chemical Characterization of Tailings

\begin{tabular}{|c|c|c|c|}
\hline $\begin{array}{l}\text { Sample } \\
\text { code }\end{array}$ & Latitude/longitude & $\begin{array}{l}\text { Total mercury } \\
\text { concentration } \\
(\mathrm{mg} / \mathrm{kg})\end{array}$ & pH \\
\hline T1 & $\begin{array}{c}110^{\circ} 33^{\prime} 44,474 ” \mathrm{E} \\
7^{\circ} 50^{\prime} 1,820^{\prime \prime} \mathrm{S}\end{array}$ & 352.32 & 8.56 \\
\hline $\mathrm{T} 2$ & $\begin{array}{c}110^{\circ} 33^{\prime} 45,615 ” \mathrm{E} \\
7^{\circ} 50^{\prime} 1,628 ” \mathrm{~S}\end{array}$ & 326.66 & 7.76 \\
\hline T3 & $\begin{array}{c}110^{\circ} 3 ' 56,786 ” \mathrm{E} \\
7^{\circ} 50^{\prime} 16,648 ” \mathrm{~S}\end{array}$ & 164.19 & 7.88 \\
\hline $\mathrm{T} 4$ & $\begin{array}{c}110^{\circ} 3{ }^{\prime} 57,644^{\prime \prime} \mathrm{E} \\
7^{\circ} 50^{\prime} 15,453^{\prime \prime} \mathrm{S}\end{array}$ & 251.51 & 8.18 \\
\hline T5 & $\begin{array}{l}110^{\circ} 3{ }^{\prime} 49,860 " \mathrm{E} \\
7^{\circ} 50^{\prime} 31,336^{\prime \prime} \mathrm{S}\end{array}$ & 383.21 & 7.48 \\
\hline
\end{tabular}

hydrate (CSH) which plays an important role in the binding of the specimen's strength. Overall, the value of compressive strength decreased and contrast to the increasing number of tailings. According to Ganjidoust et al. [14], the greater the surface area will reduce the capability of the cement to achieve the required compressive strength. Large amounts of soil will cover the surface of an aggregate and prevent the adhesion process from cement paste.

Decreasing compressive strength also can be caused by the unstable water level required for the hardening process during curing, thus the cement hydration process was disrupted [23]. Disruption of the cement hydration process will result in reduced concrete strength [24].

The result was obtained because of the influence of cement, also because of the existence of clay on the tailings [25]. Although the more tailings would reduce the value of compressive strength, the composition of adequate clay-type soil actually might increase the value of compressive strength. According to He et al. [26],

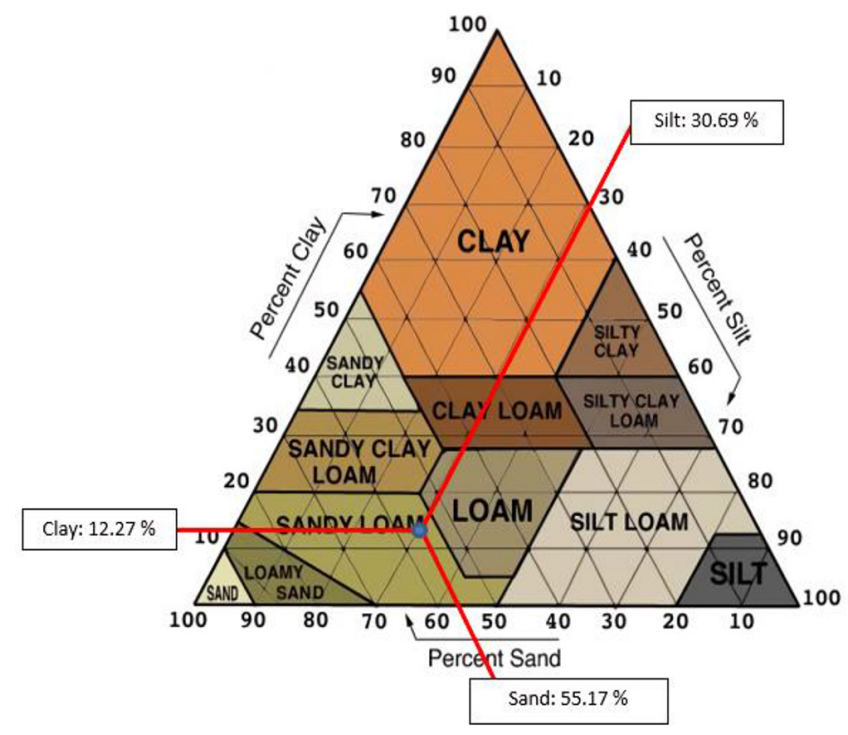

Fig. 2. Soil texture triangle.

Table 3. Value of Compressive Strength

\begin{tabular}{|c|c|c|c|c|c|c|}
\hline \multirow{2}{*}{$\begin{array}{l}\text { Composition } \\
\text { PC : Tailings }\end{array}$} & \multicolumn{2}{|c|}{ Compressive strength Objects 1} & \multicolumn{2}{|c|}{ Compressive strength Objects 2} & \multicolumn{2}{|c|}{ Average value } \\
\hline & $\left(\operatorname{ton} / \mathrm{m}^{2}\right)$ & MPa & $\left(\operatorname{ton} / \mathrm{m}^{2}\right)$ & MPa & $\left(\operatorname{ton} / \mathrm{m}^{2}\right)$ & MPa \\
\hline 100:0 & 2,270 & 22.261 & 2,144 & 21.025 & 2,207 & 21.643 \\
\hline 90:10 & 3,281 & 32.176 & 3,672 & 36.010 & 3,477 & 34.098 \\
\hline $80: 20$ & 3,880 & 38.050 & 3,910 & 38.344 & 3,895 & 38.197 \\
\hline $70: 30$ & 2,307 & 22.624 & 3,281 & 32.176 & 2,794 & 27.340 \\
\hline $60: 40$ & 2,749 & 26.958 & 2,171 & 21.290 & 2,460 & 24.124 \\
\hline $50: 50$ & 2,697 & 26.449 & 2,076 & 20.359 & 2,387 & 23.408 \\
\hline $40: 60$ & 1,149 & 11.268 & 1,266 & 12.415 & 1,207 & 11.837 \\
\hline $30: 70$ & 1,222 & 11.984 & 1,082 & 10.611 & 1,152 & 11.297 \\
\hline $20: 80$ & 714 & 7.002 & 753 & 7.384 & 734 & 7.198 \\
\hline $10: 90$ & 240 & 2.354 & 275 & 2.697 & 257 & 2.520 \\
\hline
\end{tabular}


refers to ASTM C 618 that the content of $\mathrm{SiO}_{2}+\mathrm{Al}_{2} \mathrm{O}_{3}+\mathrm{Fe}_{2} \mathrm{O}_{3}$ in natural pozzolan should reach $70 \mathrm{wt} \%$, space clay generally complies this chemical composition. The structure of crystal, chemical, and particle properties of each clay type differ and influence the activity of pozzolan in achieving the resulting mortar strength. Clay permeability also affects the value of compressive strength because the density is better if the permeability is low. So the potential of the cavity contained in the specimen will be decreased [27].

At 100:0 composition in both samples, the value of compressive strength decreased although 100\% cement composites. This could be caused by the large amount of $\mathrm{Ca}(\mathrm{OH})_{2}$ content contained in the specimen. According to Sari [28], during the hydration process on cement, a $\mathrm{Ca}(\mathrm{OH})_{2}$ particle will arise which causes the cement strength to decrease and cause the expansion of the concrete surface. The addition of pozzolan containing silica and alumina into cement will react with $\mathrm{Ca}(\mathrm{OH})_{2}$ to form calcium silicate hydrate and calcium aluminate hydrate. [29]. Calcium silicate hydrate and calcium aluminate hydrate plays the main roles in hardening and cement resistance. In this study, the soil contained in clay-type tailings might have silica and aluminate content. According to Faisal [30], reactions that occur between $\mathrm{Ca}(\mathrm{OH})_{2}$ and $\mathrm{SiO}_{2}$ can be written as follows:

$$
\mathrm{Ca}(\mathrm{OH})_{2}+\mathrm{SiO}_{2} \rightarrow \text { xCaO. } \mathrm{YSiO}_{2} \cdot \mathrm{H}_{2} \mathrm{O}
$$

Where: $\mathrm{x}, \mathrm{y}$, and $\mathrm{z}=$ equivalence value

\subsection{TCLP Test}

Prior to TCLP testing, sample preparation should be performed according to US EPA Method 1311. TCLP preparation included $\mathrm{pH}$ checking and determining the extraction fluid used. There were two extraction liquids, namely extraction fluid 1 and extraction fluid 2. Extraction fluid 1 was used if the $\mathrm{pH}$ sample $<5$, and the extraction fluid 2 was used if the $\mathrm{pH}$ sample is $>5$ after addition of $3.5 \mathrm{~mL}$ of $\mathrm{HCl} 1 \mathrm{~N}$. The extraction fluid 1 comprised a mixture between a $1 \mathrm{~N} \mathrm{NaOH}$ solution, glacial acetic acid, and aquades with a mixed $\mathrm{pH}$ of $4.93 \pm 0.05$. The extraction fluid 2 comprised a mixture of glacial acetic acid solution and aquades with a $\mathrm{pH}$ of $2.88 \pm 0.05$. Mixed samples with the extraction solution agitated with a rotary agitator for $18 \pm 2 \mathrm{~h}$ at a speed of $30 \pm$ $2 \mathrm{rpm}$. The filter was filtered using Whatman filter paper type $\mathrm{GF} / \mathrm{F} 47 \mathrm{~mm}$ with a pore size of $0.7 \mu \mathrm{m}$.

Mercury TCLP testing was performed using Mercury Analyzer Type VM-3000. The result of mercury TCLP in both sample variations can be seen in Table 4 .

The mercury TCLP test resulted in all samples met the TCLP-B quality standard in government Regulations (PP) No. 101 Year 2014 that is equal to $0.05 \mathrm{mg} / \mathrm{L}$. The TCLP value met the quality standard with a much lower value. The results obtained all samples had a value of $<0.0005 \mathrm{mg} / \mathrm{L}$.

From the data obtained, it can be concluded that mercury had a good precipitation process so the mercury mobility became lower. Precipitation occurs due to the reaction between ionic mercury $\left(\mathrm{Hg}^{2+}\right)$ with alkaline and carbonic compounds present in cement [30]. The reaction can be written as follows:
Table 4. TCLP Test Results

\begin{tabular}{cc}
\hline $\begin{array}{c}\text { Composition Portland cement: } \\
\text { Tailings }\end{array}$ & $\begin{array}{c}\text { Hg Concentration } \\
(\mathbf{m g} / \mathbf{L})\end{array}$ \\
$(100: 0)$ & 0.00040 \\
$(90: 10)$ & 0.00041 \\
$(80: 20)$ & 0.00042 \\
$(70: 30)$ & 0.00044 \\
$(60: 40)$ & 0.00046 \\
$(50: 50)$ & 0.00047 \\
$(40: 60)$ & 0.00048 \\
$(30: 70)$ & 0.00049 \\
$(20: 80)$ & 0.00100 \\
$(10: 90)$ & 0.00460 \\
$\left.\mathrm{Hg}^{2+}+2\left(\mathrm{OH}^{-}\right) \rightarrow \mathrm{Hg}^{(O H}\right)_{2} \downarrow$ \\
$\mathrm{Hg}^{2}(\mathrm{OH})_{2} \rightarrow \mathrm{HgO}+\mathrm{H}_{2} \mathrm{O}$ \\
$\mathrm{Hg}^{2+}+\mathrm{CO}_{3}^{2-} \rightarrow \mathrm{HgCO}_{3} \downarrow$
\end{tabular}

The crystalline structure formed from the hydration process will bind heavy metals from the waste after it becomes a precipitate of hydroxide and carbonate salt [31]. In this study, the precipitates and carbonates formed were mercury (II) oxide, mercury (II) hydroxide, and mercury (II) carbonate. The formation of hydroxide precipitates and carbonate salts on mercury was evidenced by the value of TCLP obtained in this study. The result of mercury TCLP had a much lower than the quality standard, so it could be concluded that mercury was well bonded in the form of hydroxide precipitates and carbonate salts.

\section{Conclusions}

In summary, the soil texture triangle of the total content of each type of grain, tailings are included in the category of sandy loam. Initial mercury tailings exceeded the quality standard of Government Regulations (PP) No. 101 of 2014 of 75 mg/kg, in which the active tailings contained mercury with a total concentration betwen 164.19 until $383.21 \mathrm{mg} / \mathrm{kg}$, with $\mathrm{pH}$ betwen 7.48 until 8.56. The S/S method using Portland cement on a mercury contaminated tailings was capable of meeting the required minimum compressive strength values and meeting the required TCLP value. All composition variations of tailings had higher compressive strength value than the quality standard with a minimum compressive strength value is $257 \mathrm{ton} / \mathrm{m}^{2}$ in composition $10 \%$ cement Portland and 90\% tailings. Whereas, the TCLP value was much lower than the quality standard value $<0.0005 \mathrm{mg} / \mathrm{L}$.

Based on TCLP results stabilized materials meet the established quality standards. The product of S/S in Indonesia even meet the environmental quality standard of Head of BAPEDAL No. 04 Year 1995 which collected at the place of hazardous and toxic waste. Material for practical purposes from S/S result needs further study and new regulations to be used. 


\section{References}

1. Lottermoser BG. Mine wastes characterization, treatment and environmental impacts. 3rd ed. London; 2010.

2. Setiabudi BT. Distribution of mercury due to gold mining business in Sangon Region Kulon Progo Regency DI Yogyakarta. Colloquium Field Results. 2005.

3. Larasati R, Setyono P, Sambowo KA. Economic valuation of externality of mercury in the people's gold mining and the role of local government overcoming mercury pollution case study of mining of people's gold in Kulon Progo District. Ekosains 2012;4:48-63.

4. Ogola JS, Mitullah WV, Omulo MA. Impact of gold mining on the environment and human health: A case study in the Migori Gold Belt, Kenya. Environ. Geochem. Health 2002;24: 141-157.

5. Telmer K, Stapper DA. Practical guide: Reducing mercury use in artisanal and small scale gold mining. United Nations Environment Programme. Nairobi Kenya: Geneva, Switzerland; 2012.

6. Government Regulation of the Republic of Indonesia No. 101 Year 2014 on the Management of Hazardous and Toxic Waste.

7. Fox RD. Physical/chemical treatment of organically contaminated soils and sediments. J. Air Waste Manag. Assoc. 1996;46:391-413.

8. Pavel LV, Gavrilescu M. Overview of ex situ decontamination techniques for soil cleanup. Environ. Eng. Manag. J. 2008:7:815-834.

9. Andres A, Ibanez R, Ortiz I, Irabien JA. Experimental study of the waste binder anhydrite in the solidification/stabilization process of heavy metal sludge's. J. Hazard. Mater. 1998;57: 155-168.

10. Chang JE, Lin TT, Ko MS, Liaw DS. Stabilization/solidification of sludges containing heavy metals by using cement and waste pozzolans. J. Environ. Sci. Health Part A. 1999;34:1143-1160.

11. Yang YC, Min GB. Solidification/stabilization of soil contaminated with metal: A review. J. Inst. Eng. Malaysia 2008;69:37-43.

12. Antemir A, Hills CD, Careya PJ, Magnieb MC, Polettini A. Investigation of 4 years old stablised/solidified and accelerated carbonated contaminated soil. J. Hazard. Mater. 2010;181: 543-555.

13. Weitzman L. Factor for selecting appropriate solidification/stabilization methods. J. Hazard. Mater. 1990;24: 157-168.

14. Ganjidoust H, Hassani A, Ashkiki AB. Cement based solidification/stabilization of heavy metal contaminated soils with the objective of achieving high compressive strength for the final matrix. Scientia Iranica 2009;2:107-115.

15. Karamalidis AK, Voudrias EA. Cement based stabilization/solidification of oil refinery sludge: Leaching behavior of alkanes and PAHs. J. Hazard. Mater. 2007;148:122-135.

16. Volgar EG, Lestan D. Efficiency modeling of solid- ification/stabilization of multi-metal contaminated industrial soil using cement and additives. J. Hazard. Mater. 2011;192: 753-762.

17. FRTR. Soil, sediment, bedrock and sludge treatment technologies. Solidification/stabilization USEPA, $401 \mathrm{M}$ Street, S.W., Washington D.C. 1999. https://frtr.gov/matrix2/section4/4-8.html.

18. US EPA. Methods for collection. Storage and manipulation of sediments for chemical and toxicological analyses technical manual. Washington: U.S. Environmental Protection Agency. 2001.

19. Rachman RM, Karisma ED, Trihadiningrum Y. Stabilization/solidification of mercury contaminated soil of traditional gold mining in Kulon Progo Yogyakarta, Indonesia using a mixture of Portland cement and tras soil. ARPN J. Eng. Appl. Sci. 2017;12:6380-6387

20. Decree of the Head of Environmental Impact Management Agency no. 03 of 1995 on Technical requirements for processing hazardous wastes of hazardous materials. Environmental Impact Control Agency.

21. US EPA. Toxicity characteristic leaching procedure. Washington: U.S. Environmental Protection Agency. 1992.

22. Pollard SJT, Montgomery DM, Sollars CJ, Perry R. Organic compounds in the cement-based stabilization/solidification of hazardous mixed wastes-mechanistic and process considerations. J. Hazard. Mater. 1991;28:313-327.

23. Yurmansyah I. The importance of concrete care to achieve strength values. $R \& B$ 2001;2:1-7.

24. Raheem AA, Soyingbe AA, Emenike AJ. Effect of curing method's on density and compressive strength of concrete. Int. J. Appl. Sci. Technol. 2013;3:55-64.

25. Amankwah EO, Bediako M, Kankam CK. Influence of calcined clay pozzolana on strength characteristics of Portland cement concrete. Int. J. Mater. Sci. Appl. 2014;3:410-419.

26. He C, Osbæk B, Makovicky E. Pozzolanic reactions of six principal clay minerals activation reactivity assessments and technological effects. Cement Concrete Res. 1995;25:1691-1702.

27. Mahasneh BZ, Shawabkeh RA. Compressive strength and permeability of sand-cement-clay composite and application for heavy metals stabilization. Am. J. Appl. Sci. 2004;4:1-4.

28. Sari E. Study of the utilization of Abu incinerator of TPA Keputih as cement mixture material to bind $\mathrm{Cu}$ heavy metals with solidification-stabilization process [thesis]. Environmental engineering department of Institut Teknologi Sepuluh Nopember (ITS). Surabaya; 2000.

29. Dembovskaa L, Bajarea D, Pundieneb I, Vitolaa L. Effect of pozzolanic additives on the strength development of high performance concrete. Procedia Eng. 20167;172:202-210.

30. Faisal S. Stabilization solidification of mercury soil simulation using Portland cement and fly ash [thesis]. Environmental engineering department of Institut Teknologi Sepuluh Nopember (ITS). Surabaya; 2015.

31. Trihadiningrum Y. Waste management of hazardous and toxic substances (B3). ITS Press: Surabaya; 2000. 